\title{
COMPARATIVE ANALYSIS OF BIOGENIC ELEMENTS IN ATMOSPHERICAL CONDENSATION OF BLACK SEA CRIMEAN COAST AND ROSTOV-ON-DON IN SPRING-SUMMER PERIOD OF 2016
}

\author{
Alla V. Varenik \\ Marine hydrophysical institute of RAS. Sevastopol, Russian Federation \\ Tatyana B. Filatova \\ Southern scientific center of Russian Academy of Science \\ Rostov-on-Don, Russian Federation \\ Alexey V. Kleschenkov \\ Southern scientific center of Russian Academy of Science \\ Rostov-on-Don, Russian Federation \\ science-almanac@mail.ru
}

Human activity significantly affects the substances content in the atmosphere, their natural cycles and budget. The chemical composition of atmospherical condensation is one of the main characteristics of atmospheric air pollution level. But in addition they also serve as a significant source of various substances inflow in maritime and continental ecosystems, capable to change their ecological state. Mainly this fact determines the urgency of studying the chemical composition of atmospheric precipitation.It is presented a comparative content characteristic of basic biogenic elements (inorganic nitrogen and phosphorus) in the atmospherical condensation in the background and urbanized areas on the Black Sea coast (v. Katsiveli and Sevastopol) and in the Rostov-on-Don region in May-September 2016. The difference of concentrations in condensations of background and urbanized regions is considered, the reasons of this difference are analyzed. The possible influence of condensations on the geological substate is estimated. It is shown that ammoniacal and nitrate were the basic forms of nitrogen in the atmospherical condensations of all observation points. In Rostov-on-Don, the content of ammonium was significantly higher than the content of nitrates, which can be explained by the entry of this element into the atmosphere from rice checks, located near the sampling site. The concentration of inorganic phosphorus in the atmospherical condensations of Rostov-on-Don exceeded the concentration in the Crimean coast region in 5 times, which may be connected with the influence of rice checks and a grain terminal near the sampling stations, as well as the introduction of phosphates into the atmosphere by winds blowing in the direction from the Salsky steppes.

Key words: atmospherical condensations, anorganic nitrogen, anorganic phosphorus, Sevastopol, v. Katsiveli, Rostov-on-Don.

[Вареник А.В., Филатова Т.Б., Клещенков А.В. Сравнительная характеристика содержания биогенных элементов в атмосферных осадках крымского побережья Черного моря и г. Ростова-надону в весенне-летний период 2016 года]

Деятельность человека существенно влияет на содержание веществ в атмосфере, их природные циклы и бюджет. Одной из основных характеристик уровня загрязнения атмосферного воздуха является химический состав атмосферных осадков. Они также служат и значительным источником поступления различных веществ в морские и континентальные экосистемы, способным изменять их экологическое состояние. Именно это обусловливает актуальность изучения химического состава атмосферных осадков.Представлена сравнительная характеристика содержания в атмосферных осадках основных биогенных элементов (неорганического азота и фросфора) в фоновых и урбанизированных районах на черноморском побережье (п. Кацивели и г. Севастополь) и в районе г. Ростов-на-Дону в мае-сентябре 2016 года. Рассматривается различие концентраций в осадках фоновых и урбанизированных районов, проанализированы причины этого различия. Оценено возможное влияние осадков на подстилающую поверхность. Показано, что в атмосферных осадках всех пунктов наблюдения основными формами азота были аммонийный и нитратный. При этом в пробах г. Ростов-на-Дону содержание аммония значительно превышало содержание нитратов, что может объясняться поступлением этого элемента в атмосферу с рисовых чеков, находящихся поблизости от места отбора проб. Концентрация неорганического фосфора в атмосферных осад- 
ках г. Ростов-на-дону превышала концентрации в районе Крымского побережья в 5 раз, что может быть связано с влиянием рисовых чеков и зернового терминала недалеко от станций отбора проб, а также с привнесением фоссратов в атмосферу ветрами, дующими по направлению от Сальских степей.

Ключевые слова: атмосферные осадки, неорганический азот, неорганический фросфор, г. Севастополь, п. Кацивели, г. Ростов-на-Дону.

Alla V. Varenik - Marine hydrophysical institute of RAS. Sevastopol, Russian Federation.

Tatyana B. Filatova- scientific worker. Southern scientific center of Russian Academy of Science. Rostov-onDon, Russian Federation.

Alexey V. Kleschenkov - candidate of geology, head of the department. Southern scientific center of Russian Academy of Science. Rostov-on-Don, Russian Federation.

Вареник Алла Валерьевна - Морской гидрофизический институт РАН. г. Севастополь, Россия. Филатова Татьяна Борисовна - научный сотрудник. Южный научный иентр РАН. Ростов-на-Дону, Россия.

Клещенков Алексей Владимирович - кандидат геологических наук, заведующий отделом. ЮжныйнаучныйцентрРАН. Ростов-на-Дону, Россия.

Chemical composition formation of the atmospherical precipitation occurs under the influence of various factors, among which, first of all, the content of various substances in the atmospheric air. Releases of biogenic matters to the atmosphere can be of natural and anthropogenic character. Human activity - agriculture and industrial production of ammonia (ammonium nitrogen), industrial production of azotic acid, exhaust gases from transport and fuel combustion (nitrogen oxides) are usually considered to be the source of nitrogen[1]. At the same time, phosphorus in the atmosphere has as anthropogenic origin (metallurgical production, production and application of fertilizers to the soil), so natural (wind erosion, volcanic activity, generation of biogenic aerosols by plants) [2]. Removal of pollutants from the atmosphere is carried out in two ways: with atmospherical condensation and dry fallout. Most intensively, they are excreted with atmospherical condensation [3].Data about the chemical composition of atmospherical condensation samples can serve as an indirect integral indicator of air pollution.

Atmospherical condensation characteristics over a specific territory directly depend on the physical and geographical conditions and can often vary in space and time, for instance, under the influenceof the circulation processes. The composition of rainwater largely depends on the environmental situation of the place where the cloud was formed, it is determined by the intensity of emission sources, meteorological conditions, the region of condensation nuclei formation, and the atmosphere state along the route of air masses, carrying condensation to the region.

The content of individual components in atmosphericalcondensation, primarily depends on the amount of condensation: the more condensation, the less their contamination. And this dependence is always manifested - both in individual samples, and in averaged over the months, seasons, and years. Also the direction of the wind, and the intensity of condensation, and the weather, which precedes the condensation(the duration of the period without condensation) influence significantly. The samples of rainwater, collected in a few minutes after the beginning of the rain, will be "cleaner" than those taken immediately, and they also may have other values of the contained substances [4].

Between May and October 2016 in Rostov-on-Don, 14 single samples of atmospheric condensation were collected at the station, located on the left bank of the Don River. In Sevastopol for a comparable period, 26 condensation samples were taken and processed, in Katsiveli settlement (background point of the Crimean coast) - 14 samples. 
The selection and treatment of atmospheric condensation samples for the biogenic elements content in them was carried out in accordance with Guideline Document DD52.04.186-89 "Guidelines for the control of atmospheric pollution". For analysis, it was especially important to collect the first, most polluted condensation. During the selection of atmosphericalcondensation, foreign substances were not allowed to enter the sample in the intervals between precipitation. Single samples were collected for each occurrence of precipitation. During the work, hydrometeorological data were recorded, which appear to be independent characteristics of the state of the natural environment, and also used to interpret the dynamics of the biogenic matters content in the atmosphere.

At all points of observation, samples were taken to the condensation collector, which opens only at the time of precipitation, in accordance with recommendations [5; 6]. An automatic condensation collector for sampling atmospherical precipitation and aerosols that meets WMO requirements was established in Katsiveli village according to the $\mathrm{MHI}$ order and accomplished in the optics and atmosphere Institute of V.E. Zueva of Siberian RAS department (Tomsk) (pic. 1).

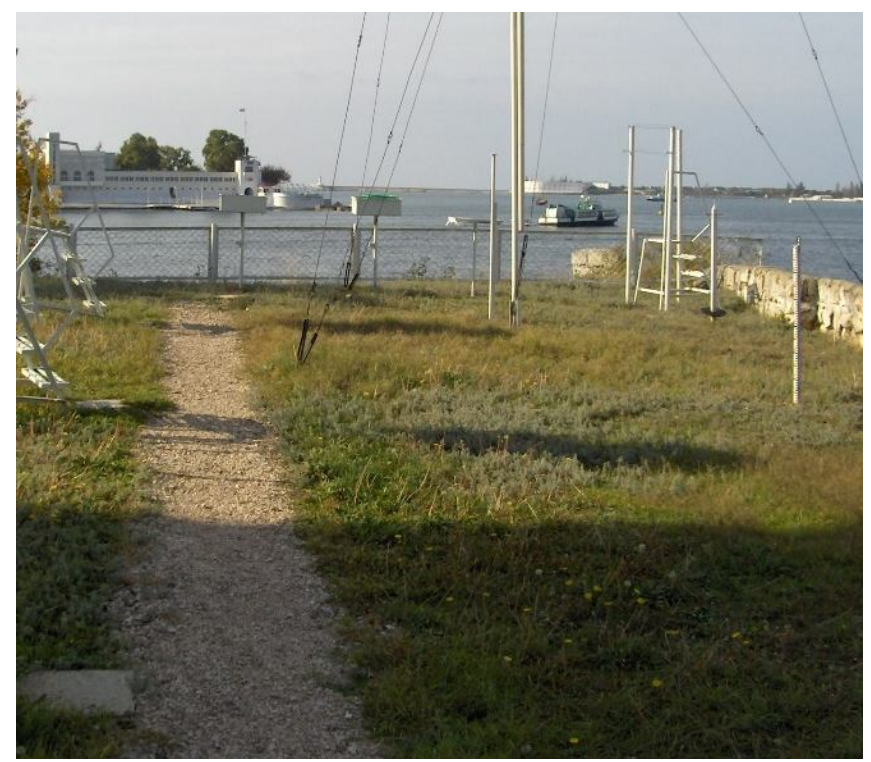

a

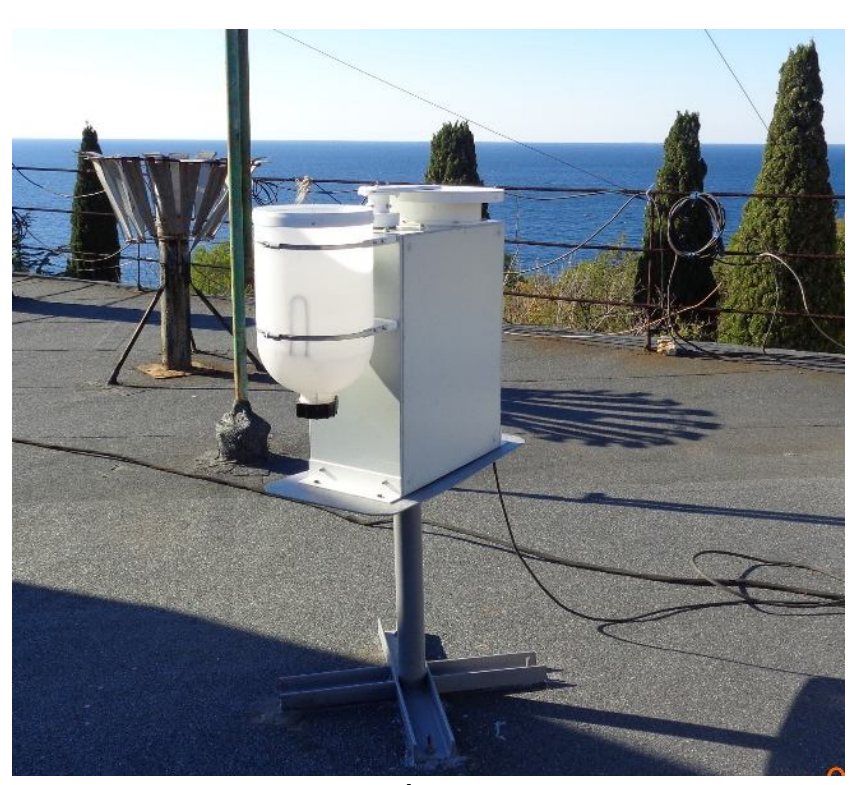

b

Picture 1. Atmosphericalcondensation sampling station (a - d. Sevastopol, b- v. Katsiveli)

Polyethylene jars (bottles) intended for taking and storage of the samples were delivered to the station from the chemical laboratory thoroughly washed, closed and numbered. They were opened only at the time of precipitation sampling. At the end of the rain, the precipitation was poured into prepared polyethylene jars and delivered to a chemical laboratory. If it was not possible to immediately deliver samples, they were stored in the refrigerator for 24 hours. Precipitation, which number did not allow the chemical analysis conduction, was not processed.

After filtering the selected samples of rainwater, the concentrations of the biogenic matters were determined using standard techniques recommended for use in hydrochemical studies: phosphates- according to the method of Morphi and Raili [7]; nitrites - according to the method of Bandschneider andRobinson [8]; nitrates - according to the method ofMorris and Raili (in modification of Grasskhoff; StriklandParsons; Sapozhnikov, Gusarova, Lukashev) [8]; ammonium ions - according to the method of Sagee-Solorzano[9]. 
Taking into account that separate quality standards were not developed for atmospherical condensation, to estimate the precipitation contamination by biogenic elements we were guided by the values of the maximum allowable concentrations (MAC) for fishery reservoirs[10].According to the norms of MAC for ammonia nitrogen it comprises 2900 $\mathrm{mkgN} / \mathrm{dm}^{3}$ under the salineness $13-34 \%$ and $400 \mathrm{mkgN} / \mathrm{dm}^{3}$ under the salineness less than $13 \%$, nitrate nitrogen $-9000 \mathrm{mkgN} / \mathrm{dm}^{3}$, nitrite nitrogen $-20 \mathrm{mkgN} / \mathrm{dm}$, phosphates $50 \mathrm{mkgP} / \mathrm{dm}^{3}$ (oligotrophic waters), $150 \mathrm{mkgPdm}^{3}$ (mesotrophic waters) и $200 \mathrm{mkgP} / \mathrm{dm}$ (eutrophic waters).

The content of ammonium nitrogen in the atmospheric precipitation in the city of Rostov-on-Don varied from 18.57 to 83.57 micromole / dm3, the range of nitrite concentration changes was 0.43-4.86 micromole / dm3, nitrates 21.43-56, 43 micromole / dm3, phosphates - 1.77-16.13 micromole / dm3. At the same time, the content of ammonium in the precipitation exceeded the MAC value for fishery waters (for salinity less than $13 \%$ ) in 10 cases from the total number of samples taken, nitrites in 3 cases, and phosphates in 7 cases (in comparison with the MAC for eutrophic waters).In the case of nitrate nitrogen, the values of concentrations exceeding the MAC were not determined.

The atmospherical precipitation of the Crimean coast was also characterized by the increased concentrations of biogenic elements. The nitrite content varied in the range 0.19-6.95 micromole / dm3, ammonium 11.47-166.26 micromole / dm3, nitrates 25.77302.63 micromole / dm3, phosphates 0.19-4, 66 micromole / dm3.In 7 cases the concentration of nitrite nitrogen exceeded the maximum admissible concentration for fishery waters. The phosphate content in one case approximated the MAC value for mesotrophic water bodies, to which the Black Sea belongs [11], but did not exceed it.

The average biogenic matters concentrations in the atmospherical precipitation samples for the observation period are represented in the table.

Table. the average concentration of biogenic matters in the rainwater samples, micromole $/ \mathrm{dm}^{3}$

\begin{tabular}{|l|c|c|c|c|}
\hline Observationpoint & $\begin{array}{c}\mathrm{NH}_{4}^{+}, \\
\text {micromole } / \mathrm{dm}^{3}\end{array}$ & $\begin{array}{c}\mathrm{NO}_{3}^{-}, \\
\text {micromole } \\
\mathrm{dm}^{3}\end{array}$ & $\begin{array}{c}\mathrm{NO}_{2}^{-}, \\
\text {micromole } / \mathrm{dm}^{3}\end{array}$ & $\begin{array}{c}\mathrm{PO}_{4}{ }^{3-}, \\
\text { micromole } / \mathrm{dm}\end{array}$ \\
\hline Rostov-on-Don & 39,27 & 35,63 & 1,20 & 8,20 \\
\hline Sevastopol & 51,83 & 71,52 & 2,58 & 0,97 \\
\hline Katsiveli & 63,4 & 48,16 & 0,23 & 0,76 \\
\hline
\end{tabular}

As can be seen from the table, the average content of nitrates in the samples of Sevastopol was almost in 1.5 times higher than in Katsiveli and in higher 2 times in than in Rostov-on-Don. The predominance of nitrates in the city of Sevastopol can point to the element anthropogenic arrival, associated with emissions increase from road transport in the city in the beginning of the holiday season, from maritime transport, based near the sampling point, and also from air as a result of visibly intensified civil and military aviation.

Ammonium and nitrates were the main forms of nitrogen, entered with atmospheric precipitation at all points of observation, nitrites did not exceed $2 \%$ (pic. 2). 

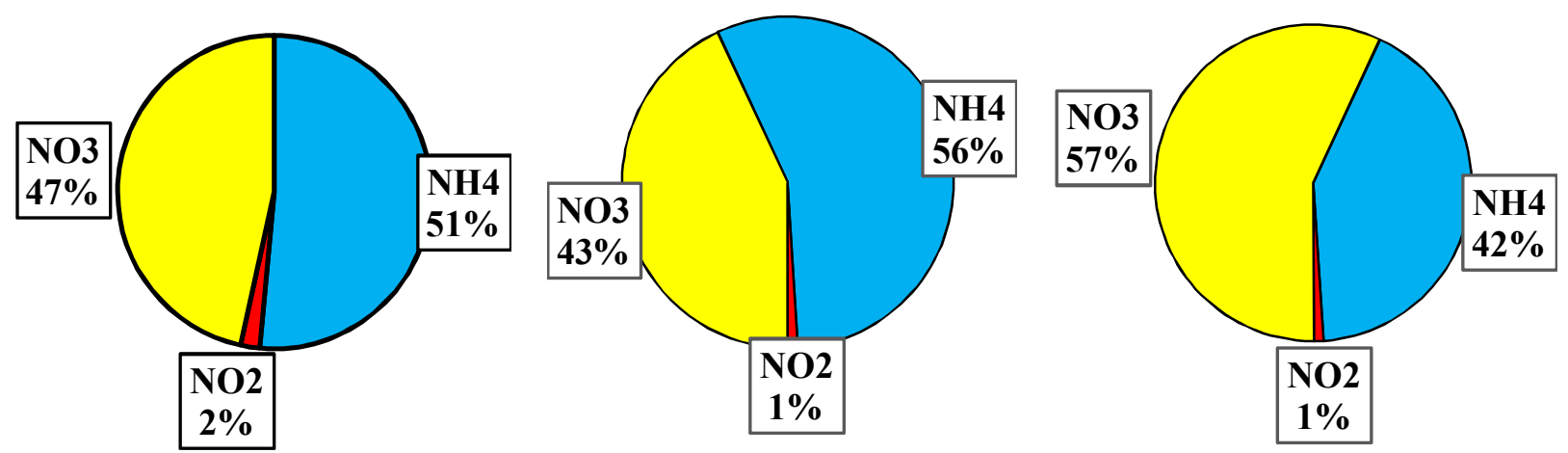

Picture 2. The relative contribution of anorganic nitrogen froms in the samples of the at mospherical condensation ( $\mathrm{a}-\mathrm{cRostov}-\mathrm{on}-\mathrm{Don}, \mathrm{b}-\mathrm{cv}$. Katsiveli, c - cSevastopol)

As can be seen from Figure 2, on the left bank of the Don, the percentage ratio of nitrates to ammonium was practically the same: ammonium accounted for $51 \%$ of inorganic nitrogen and $47 \%$ for nitrates. As one can see from the picture 2 , the percentage ratio ofnitrates and ammonium was practically equal on the left bank of the Don river: ammonium accounted for $51 \%$ of inorganic nitrogen and $47 \%$ for nitrates. The high concentration of ammonium in comparison with nitrates in the sediments of Rostov-on-Don may indicate about the influence on the atmosphere air contamination condition by check plots, situated near the sampling place. the percentage ratio of ammonium and nitrates in the atmosphericalcondensationat the background station in the village of Katsiveliwas close to the ratio of elements in the precipitation on the left bank of the Don and comprised 56:43, while it was the opposite in the urbanized area of Sevastopol- 42:57.

After a long period without precipitation in Rostov-on-Don (for example, from 30 of June to 21 of July), increased concentrations of ammonium and nitrate ions (81.42 and 45.71 micromole / dm3, respectively) are determined in rainwater samples. At the next rain (a day later), the content of these compounds decreased by 2-4 times. Then, after 10 days of hot weather without precipitation, the concentrations, exceeding the previous ones in 23 times were determined. The same decrease was observed in May, during rainwater sampling for several days without interruption.Similar fluctuations were noted in September, when there was no precipitation from July 31 to September 20, and on September 20, the samples showed an increased content of ammonium and nitrate nitrogen (55.71 and 60 micromole / dm3, respectively).In the samples, collected in the next few days, the content of these biogenic matters decreased. There was no such tendencyin Sevastopol and Katsiveli village.

The amount of precipitation is also one of the main factors, determining the concentration of nutrients in atmospherical condensation. This particularly applies to soluble elements, such as anorganic nitrogen.Graphs ofanorganic nitrogen concentration change in the precipitation from its quantity were builtfor all points of observation(pic. 3). 


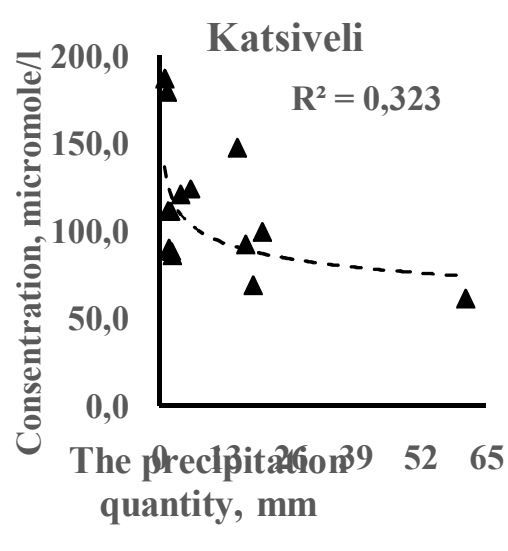

a

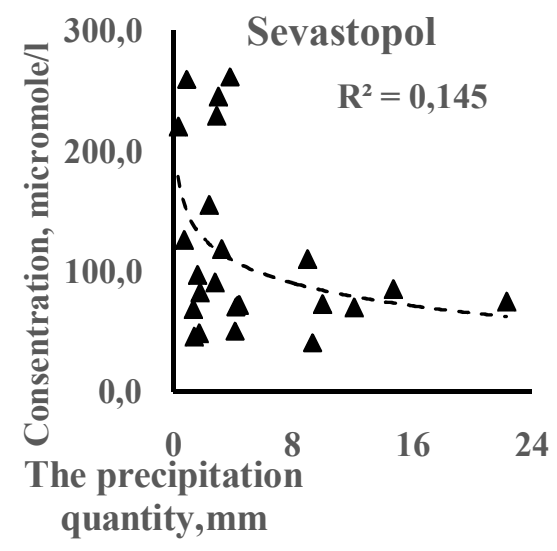

b

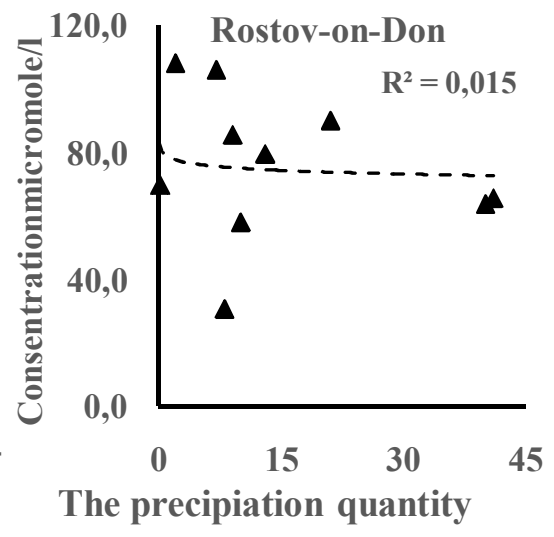

C

Picture 3. The anorganic nitrogen alteration in atmospherical precipitation samplings

$$
\text { ( } a \text { - cv. Katsiveli,b - cSevastopol, c - cRostov-on-Don) }
$$

As can be seen from pic. 3 , in the condensation of the Crimean coast there is a decrease in concentration with an increase in the amount of precipitation. This is explained by the dilution effect of the samples, when the main amount of pollutants is washed out of the atmosphere by the initial portion of precipitation, and dilution occurs with further precipitation of rain[12].Statistically insignificant decrease of concentration is observed for samples, selected in Rostov-on-Don.

The average concentration of anorganic phosphorus at the sampling stations near the Crimean coast comprised: 0.97 micromole / I in Sevastopol, 0.76 micromole / I in Katsiveli.In Rostov-on-Don, the average phosphate content in the sediments was 8.20 micromole / I.Attention is drawn to the considerably higher concentrations of phosphates in the atmospheric precipitation of Rostov-on-Don in comparison with the precipitation near the Crimean coast. This also can be connected with phosphate fertilizers using for check plots. In addition, phosphates can enter the atmosphere with winds, blowing from the southeast, and bringing this element from Salsk steppes. The Rostov grain terminal activity can also contribute to this.

Taking into account that atmospherical condensation deliversbiogenic elements togeological substate, including reservoirs, it is possible to trace their impact on aquatic ecosystems, in particular, on the ecosystems of the coastal regions of the Black Sea and the Don River. To analyze the effect of precipitation on aquatic ecosystems, one can use the ratio of Redfield [13] nitrogen to phosphorus, which equal to 16: 1 . In the sediments of Sevastopol this ratio for the period under study comprised 130: 1, in Katsiveli- 147: 1, in Rostov-on-Don - 1: 9.

As it can be seen, correlation values of the nitrogen:phosphorus in the atmospheric precipitation of the Crimean coast far exceed the original ratio of Redfield.Some researchers [13] suppose that more intensive admission of anthropogenic nitrogen in the ocean can lead to the situation that some sea areas with limitation in nitrogen will turn to the regions with limitation in phosphorus.

The reverse situation is observed in the atmospherical precipitation of Rostov-onDon: precipitation occurs on the surface of the Don River, where phosphorus presents in much larger quantities than in natural aquatic ecosystems.

From the obtained results, it can be concluded that the arrival of atmospheric precipitation can change the $\mathrm{C}: \mathrm{N}$ : $\mathrm{P}$ balance in the surface layer of the Black Sea and the river Don. 
Organized short-term monitoring of the biogenic matters content in the atmospheric precipitation of the Crimean coast and Rostov-on-Don revealed some regularities in the formation of the precipitation chemical composition.Ammonium and nitrates were the main anorganic nitrogen forms, taking place in precipitation, in all observation points. Their ratio at different sampling points varied depending on the entry sources of these elements into the atmosphere. There was a decrease in anorganic nitrogen content in the samples under the increase of the precipitation amount that may be explained as the samples dilution effect. However, this decrease was statistically insignificant in Rostov-on-Don. The increased concentrations of biogenic elements in the samples, taken on the left bank of the river Don, were observed under the increase of the "dry" period without precipitation. The concentrations were significantly reduced in the subsequent samples of precipitation.

Phosphate concentrations in atmospheric precipitation samples of the Crimean coast were in order lower than the concentrations of phosphates in Rostov-on-Don. This may be connected withphosphate fertilizers using for check plots, with entrance of phosphates with winds, blowing from southeast, and bringing this element from the Salsk steppes. The activity of Rostov grain terminal can also contribute to this. However, the concentration series are rather small, and further work is planned to specify the data, obtained during this study. The work is carried out within the framework of state target of MHI RAS on the theme 0827-2014-0010 "Complex interdisciplinary researches of oceanologic processes, determining functioning and evolution of Black and Azov sea ecosystems, on the basis of modern control methods of sea environment state and GRID-technologies"(cipher "Fundamental oceanology") andIAZSSC RASPAHon the theme 01-17-03 "Modern state and long-term variability of south Russia seas littoral ecosystems".

\section{Лumepamypa}

1. Баранов А.Н., Янченко Н.И. Состав атмосферных выпадений в районе города Братска // Системы. Методы, Технологии. 2010. № 6.

2. ГОСТ 17.1.5.05-85. Охрана природы. Гидросфера. Общие требования к отбору проб поверхностных и морских вод, льда и атмосферных осадков. М., 1986.

3. Методы гидрохимических исследований основных биогенных элементов / ред. В.В. Сапожников. М., 1988.

4. Приказ Федерального Агенства по Рыболовству № 16326 от 09.02.2010.

5. РД 52.04.186-89 Руководство по контролю загрязнения атмосфреры. ЧАСТЬ II Региональное загрязнение атмосфреры.

6. РД 52.24.382-2006. Массовая концентрация фосфратов и полифосфатов в водах. Методика выполнения измерений фотометрическим методом. Ростов-наДону, 2006.

7. РД 52.24.383-2005. Массовая концентрация аммиака и ионов аммония в водах. Методика выполнения измерений фотометрическим методом в виде индофенолового синего. Ростов-на-Дону, 2005.

8. Свистов П. Ф., Полищук А. И. Атмосфрерные осадки над городами и регионами России // Природа. 2014. № 3.

9. Burlakova Z.P., Eremeeva L.V., Konovalov S.K. Inventory and fluxes of particulate organic carbon and nitrogen in the Black Sea oxic/anoxic water column // Oceanography of the Eastern Mediterranean and Black Sea. Proceedingofthe "Second International Conference on Oceanography of the Eastern Mediterranean and Black Sea: Similarities and Differences of Two Interconnected Basins", 14 - 18 October 2002. Ankara, Turkey, 2003. 
10. HerutB., KromM.D., PanG., Mortimer R. AtmosphericinputofnitrogenandphosphorustotheSoutheastMediterranean: Sources, fluxes, andpossibleimpact // LimnologyandOceanography.1999.44(7).

11. Lucinda J. Spokes. Is the atmosphere really an important source of reactive nitrogen to coastal waters? / Lucinda J. Spokes, Tim D. Jickells // Continental Shelf Research. 2005. № 25.

12. Mahowald N. Global distribution of atmospheric phosphorussources, concentrations and deposition rates, and anthropogenic impacts. Global Biogeochem. No 22. 2008.

13. Wasmund N., Andrushatis A., Lysiak-Pastuszak E. Trophicstatusofthesoutheastern Baltic Sea: a comparison of coastal and open areas // Estuar.Coas. Shelf Sci. 2001. Vol. 53.

\section{References}

1. BaranovA.N., YanchenkoN.I.Atmospherical condensations composition in the Bratsk region / A.N. Baranov, N.I. Yanchenko// Systems. Methods, technologies. 2010. No6.

2. GOST 17.1.5.05-85. Nature conservation. Hydrosphere. General requirements to samples taking of superficial and sea waters, ice andatmospherical condensations. M., 1986.

3. Hydrochemical researchers methods based on biogenic elements / edit. V. V. Sapozhnikov. M., 1988.

4. Order of the Federal Agency for Fisheries No 16326 from 09.02.2010.

5. DD 52.04.186-89 Supervision manual on atmosphere pollution. PART II Regional contamination of atmosphere.

6. DD 52.24.382-2006.Phosphates and polyphosphates mass concentration in the waters. Measures fulfillment technique by photometric method. Rostov-on-Don, 2006.

7. DD 52.24.383-2005. Mass concentration of ammonia and ammonium ions in water. The procedure for performing measurements by the photometric method in the form of indophenol blue. Rostov-on-Don, 2005.

8. Svistov P. F., Polischuk A. I. Atmospherical condensations over the mountains and regions of Russia // Priroda. 2014. No 3.

9. Burlakova Z.P., Eremeeva L.V., Konovalov S.K. Inventory and fluxes of particulate organic carbon and nitrogen in the Black Sea oxic/anoxic water column // Oceanography of the Eastern Mediterranean and Black Sea. Proceeding of the "Second International Conference on Oceanography of the Eastern Mediterranean and Black Sea: Similarities and Differences of Two Interconnected Basins", 14 - 18 October 2002. Ankara, Turkey, 2003.

10. Herut B., Krom M.D., Pan G., Mortimer R. Atmospheric input of nitrogen and phosphorus to the Southeast Mediterranean: Sources, fluxes, and possible impact // Limnology and Oceanography. 1999. 44(7).

11. Lucinda J. Spokes. Is the atmosphere really an important source of reactive nitrogen to coastal waters? / Lucinda J. Spokes, Tim D. Jickells // Continental Shelf Research. 2005. No 25.

12. Mahowald N. Global distribution of atmospheric phosphorus sources, concentrations and deposition rates, and anthropogenic impacts. Global Biogeochem. No 22. 2008.

13. Wasmund N., Andrushatis A., Lysiak-Pastuszak E. Trophic status of the southeastern Baltic Sea: a comparison of coastal and open areas // Estuar. Coas. Shelf Sci. 2001. Vol. 53. 